\title{
Synthesis and evaluation of cytotoxic activities of some 1,4-disubstituted thiosemicarbazides, 2,5-disubstituted-1,3,4- thiadiazoles and 1,2,4-triazole-5-thiones derived from benzilic acid hydrazide
}

\author{
Işıl Çoruh', Sevim Rollas', Suna Özbaş Turan², Jülide Akbuğa²
}

\begin{abstract}
This study describes the synthesis of novel 1-( $\alpha, \alpha$-diphenyl- $\alpha$-hydroxy)acetyl-4substitutedthiosemicarbazide (2a-k), [5-(substitutedamino)-1,3,4-thiadiazole-2-yl] (diphenyl) methanol (3a-b) and 3-[hydroxy(diphenyl)methyl]-4-(nonsusbtituted/substituted)-2,4-dihydro-5H-1,2,4-triazole-5-thione derivatives (4a-c) and evaluation of their cytotoxic activities. In the course of the syntheses benzilic acid methyl ester was reacted with hydrazine hydrate in absolute ethanol to afford benzilic acid hydrazide (1). Reaction of 1 with appropriate alkyl/ arylisothiocyanates gave 1-( $\alpha, \alpha$-diphenyl- $\alpha$-hydroxy)acetyl-4-substitutedthiosemicarbazide (2a-k). [5-(substitutedamino)-1,3,4-thiadiazole-2-yl] (diphenyl)methanol derivatives (3a-b) were obtained by cyclization of $2 \mathrm{a}$ and $2 \mathrm{c}$ with concentrated sulphuric acid. On the other hand, 3-[hydroxy(diphenyl)methyl]-4-(nonsusbtituted/substituted)-2,4-dihydro-5H-1,2,4-triazole-5-thione (4a-c) were obtained by cyclization of $2 \mathrm{c}, 2 \mathrm{~d}$ and $2 \mathrm{~g}$ with $2 \mathrm{~N} \mathrm{NaOH}$. The structures of the new compounds were confirmed by the data obtained from elemental analysis, HPLC, UV, IR, 1H-NMR, 13C-NMR, HSQC and MS spectra. Compounds 2a, 2c-k, 3b and 4b were selected for cytotoxic screening by using HEK293 cell line of MTT assay. The highest inhibition were confirmed as $50.23 \%$ at $10 \mathrm{mg} / \mathrm{ml}$ for the compound 1-( $\alpha, \alpha$-diphenyl- $\alpha$ hydroxy)acetyl-4-cyclohexylmethylthiosemicarbazide (2e).
\end{abstract}

KEY WORDS: thiosemicarbazide, thiadiazole, 1,2,4-triazole-5-thione, cytotoxic activity.

\section{INTRODUCTION}

The use of thiosemicarbazide in organic synthesis has become a classical strategy for the synthesis of several heterocycles. Among the increasing number of heterocyclic sulphur and nitrogen containing compounds, which are being pursued in both industry and academia, 1,3,4-thiadiazole and 1,2,4-triazole derivatives are also interesting targets for drug design. Therefore, there have been intense investigations on 1,4-disubstitutedthiosemicarbazide, 1,3,4-thiadiazole and 1,2,4-triazole-thione compounds.

1,4-Disubstituted-thiosemicarbazide are biologically versatile compounds displaying a variety of biological effects which include anti-inflammatory (1), antimycobacterial $(2,3)$, antimicrobial (4$6)$, antifungal $(7)$, antibacterial $(8,9)$ and antiviral (3) activities. 2,5-Disubstituted 1,3,4-thiadiazoles, synthesis of which frequently include the reaction of acylthiosemicarbazides with acidic reagents such as concentrated sulfuric acid, possess various biological properties such as anticonvulsant $(10)$, antifungal $(11,12)$, antituberculosis (13$15)$, antimicrobial $(16,17)$, anti-inflammatory (18), cytotoxic (19), and antiproliferative (20), antioxidant (21-22) activities. In addition, 1,2,4-triazole-thiones which possess important pharmacological activities such as anticonvulsant (23), anti-inflammatory (24-28), antibacterial (29), cytotoxic $(30,31)$, antimicrobial (32), anticancer $(33,34)$, and antiviral $(35)$ have found wide use in medicinal chemistry as common structures.

The present communication deals with the synthesis of 1-(a,a-diphenyl-a-hydroxy) acetyl-4substitutedthiosemicarbazide (2a-k), [5-(substi-
AFFILIATIONS

${ }^{1}$ Marmara Üniversitesi. Eczacılık Fakültesi, Farmasötik Kimya, İstanbul, Türkiye

2Marmara Üniversitesi.

Eczacılık Fakültesi,

Farmasötik Biyoteknoloji,

Istanbul, Türkiye

CORRESPONDENCE

Sevim Rollas

E-mail:

srollas@marmara.edu.tr

Received:

28.11.2011

Revision:

13.12.2011

Accepted:

15.12 .2011 
tutedamino) -1,3,4-thiadiazole-2-yl] (diphenyl) methanol (3ab) and 3-[hydroxy (diphenyl) methyl]-4-(nonsusbtituted/ substituted)-2,4-dihydro-5H-1,2,4-triazole-5-thione derivatives (4a-c). Their structures were confirmed by means of UV, IR, ${ }^{1} \mathrm{H}-\mathrm{NMR}$, Mass spectral data and elemental analysis. All the synthesized compounds were screened for their cytotoxic activities by using HEK293 cell line of MTT assay.

\section{EXPERIMENTAL}

\section{Chemistry}

All solvents and chemicals used in this study were supplied from Aldrich, Merck and Fluka and used without purification. Melting points $\left({ }^{\circ} \mathrm{C}\right)$ were measured using Schmelzpunktbestimmer SMP II melting point apparatus, uncorrected. The reactions were monitored on Merck pre-coated aluminium TLC plates $60 \mathrm{~F}-254$ and the products were visualized by UV-light using ethyl asetate and ether (50:50, v/v) as solvent system. The UV spectra were recorded on a Schimadzu UV-1601 spectrophotometer. The Infrared spectra were recorded on Schimadzu FTIR-8400S Spectrophotometer and expressed in wave number $\mathrm{v}\left(\mathrm{cm}^{-1}\right)$. ${ }^{1} \mathrm{H}-\mathrm{NMR}$ spectra were recorded on Bruker AVANCE-DPX 400 and Varian Mercury Spectrometer at 400 $\mathrm{MHz}$, using DMSO- $d_{6}$ as a solvent; tetramethylsilane (TMS) was used as internal standard. All NMR chemical shifts are reported as $\delta$ values in parts per million (ppm) and coupling constant $(J)$ are given in hertz $(\mathrm{Hz})$. Mass spectra were obtained by using Agilent 1100 LC-MS and Waters 2695 Alliance Micromass. ${ }^{1} \mathrm{H}-\mathrm{NMR}$ and Mass analyses were provided by Faculty of Pharmacy Center Laboratory (Ankara University) and the Scientific and Technical Research Council of Turkey, TÜBİTAK (Ankara).

\section{Preparation of benzilic acid hydrazide (1)}

Hydrazine hydrate $(0.03 \mathrm{~mol}, 80 \%)$ was added to benzilic acid methyl ester $(0.01 \mathrm{~mol})$. The mixture was refluxed at $100^{\circ} \mathrm{C}$ for 30 minutes. After adding ethanol $(10.0 \mathrm{~mL})$, the mixture was heated in a water steam bath for two hour. The residue was filtered, washed with water and recrystallized from ethanol. mp: 171-172 ${ }^{\circ} \mathrm{C}$, (lit. [36] mp. 169-170 ${ }^{\circ} \mathrm{C}$ ).

General procedure for the synthesis of 1-(a,a-diphenyl-ahydroxy)acetyl-4-(substituted)thiosemicarbazide (2a-k)

Equimolar amounts of benzilic acid hydrazide (0.01 mol) and appropriate alkyl/aryl isothiocyanates were refluxed in ethanol $(30 \mathrm{~mL})$ for 2-3 hours. The crystalline product was filtered and recrystallized from ethanol to obtain 1,4-disubstitutedthiosemicarbazides.

1-(a,a-diphenyl-a-hydroxy)acetyl-4-(2-chloroethyl)thiosemicarbazide (2a): White crystals, yield 86\%, mp 260-262 ${ }^{\circ} \mathrm{C}$; IR $\left(\mathrm{v}_{\max }, \mathrm{cm}^{-1}\right)$ : $3248(\mathrm{NH}), 1707(\mathrm{C}=\mathrm{O}), 1244(\mathrm{C}=\mathrm{S}) .{ }^{1} \mathrm{H}$ NMR $(400$ $\left.\mathrm{MHz}, \mathrm{DMSO}-d_{6}\right) \delta(\mathrm{ppm}): 3.51\left(-\mathrm{CH}_{2} \mathrm{Cl}\right.$, protons are shadowed with solvent), $3.97\left(2 \mathrm{H}, \mathrm{t}, \mathrm{NHCH}_{2}\right), 7.08(1 \mathrm{H}, \mathrm{s}, \mathrm{OH}), 7.21-7.63$ $(10 \mathrm{H}, \mathrm{m}, \mathrm{Ar}-\mathrm{H}), 10.80\left(1 \mathrm{H}, \mathrm{N}^{4}-\mathrm{H}\right), 11.09\left(1 \mathrm{H}, \mathrm{s}, \mathrm{N}^{2}-\mathrm{H}\right), 12.00$ $(1 \mathrm{H}, \mathrm{s}, \mathrm{N} 1-\mathrm{H})$. Anal. Calcd for $\mathrm{C}_{17} \mathrm{H}_{18} \mathrm{ClN}_{3} \mathrm{O}_{2} \mathrm{~S}$ (363.86): C, 56.12; H, 4.99; N, 11.55; S, 8.81\%. Found: C, 56.23; H, 4.85; N, 11.48; S, 8.99\%. (API-ES $\left.{ }^{+}, \mathrm{m} / \mathrm{z}, \%\right): 328\left[\mathrm{M}^{+}-35.5\right]$ (100), 310, 282, 210, 209, 208, 178, 150, 143.

1-(a,a-diphenyl-a-hydroxy)acetyl-4-(4-cyanophenyl)thiosemicarbazide (2b): White crystals, yield $85 \%$, mp 169-173 ${ }^{\circ} \mathrm{C}$; IR $\left(\mathrm{v}_{\max }, \mathrm{cm}^{-1}\right)$ : 3363 and $3300(\mathrm{NH}), 1687(\mathrm{C}=\mathrm{O}), 1282(\mathrm{C}=\mathrm{S}) .{ }^{1} \mathrm{H}$
NMR (400 MHz, DMSO- $\left.d_{6}\right) \delta(\mathrm{ppm}): 6.82(1 \mathrm{H}, \mathrm{s}, \mathrm{OH}), 7.24-$ 7.78 (14H, m, Ar-H), $9.34\left(1 \mathrm{H}, \mathrm{N}^{2}-\mathrm{H}\right), 10.12(1 \mathrm{H}, \mathrm{s}, \mathrm{N} 1-\mathrm{H}), 10.50$ $\left(1 \mathrm{H}, \mathrm{s}, \mathrm{N}^{4}-\mathrm{H}\right)$. Anal. Calcd for $\mathrm{C}_{22} \mathrm{H}_{18} \mathrm{~N}_{4} \mathrm{O}_{2} \mathrm{~S}$ (402.46): C, 65.65; H, 4.51; N, 13.92; S, 7.97\%. Found: C, 65.33; H, 4.34; N, 14.08; S, 8.38\%. (API-ES $\left.{ }^{+}, \mathrm{m} / \mathrm{z}, \%\right): 403\left[\mathrm{M}^{+}\right], 388,386,385$ (100), 379, 366, 355, 347, 342, 307, 301, 294, 268, 264, 254, 246.

1-(a,a-diphenyl-a-hydroxy)acetyl-4-benzoylthiosemicarbazide (2c): White crystals, yield $42 \%$, mp 189-190 ${ }^{\circ} \mathrm{C}$; IR $\left(\mathrm{v}_{\max }, \mathrm{cm}^{-}\right.$ 1): $3232(\mathrm{NH}), 1674(\mathrm{C}=\mathrm{O}), 1251$ (C=S). ${ }^{1} \mathrm{H}$ NMR (400 MHz, DMSO- $\left.d_{6}\right) \delta$ (ppm): 7.28 (1H, s, OH), 7.13-8.04 (15H, m, Ar-H), 10.86 $\left(1 \mathrm{H}, \mathrm{N}^{4}-\mathrm{H}\right), 11.93\left(1 \mathrm{H}, \mathrm{s}, \mathrm{N}^{2}-\mathrm{H}\right), 13.17\left(1 \mathrm{H}, \mathrm{s}, \mathrm{N}^{1}-\mathrm{H}\right)$. Anal. Calcd for $\mathrm{C}_{22} \mathrm{H}_{19} \mathrm{~N}_{3} \mathrm{O}_{3} \mathrm{~S}$ (405.46): C, 65.17; H, 4.72; N, 10.36; S, 7.91\%. Found: C, 64.91; H, 4.60; N, 10.36; S, 7.16\%. (API-ES + , m/z, \%): $407\left(\mathrm{M}^{+}+\mathrm{H}\right)^{+}, 389$ (100), 388, 338, 276, 247, 229, 199, 157.

1-(a,a-diphenyl-a-hydroxy)acetyl-4-(4-trifluoromethoxyphenyl)thiosemicarbazide (2d): White crystals, yield $48 \%$, mp 145-146 ${ }^{\circ} \mathrm{C}$; IR ( $\left.\mathrm{v}_{\max }, \mathrm{cm}^{-1}\right): 3300$ and $3142(\mathrm{NH}), 1653$ $(\mathrm{C}=\mathrm{O}), 1261(\mathrm{C}=\mathrm{S}) .{ }^{1} \mathrm{H}$ NMR $\left(400 \mathrm{MHz}, \mathrm{DMSO}-d_{6}\right) \delta$ (ppm): $6.78(1 \mathrm{H}, \mathrm{s}, \mathrm{OH}), 7.65-7.14(12 \mathrm{H}, \mathrm{m}, \mathrm{Ar}-\mathrm{H}), 9.28\left(1 \mathrm{H}, \mathrm{N}^{4}-\mathrm{H}\right)$, $9.97\left(1 \mathrm{H}, \mathrm{s}, \mathrm{N}^{2}-\mathrm{H}\right), 10.50\left(1 \mathrm{H}, \mathrm{s}, \mathrm{N}^{1}-\mathrm{H}\right)$. Anal. Calcd for $\mathrm{C}_{22} \mathrm{H}_{18} \mathrm{~F}-$ ${ }_{3} \mathrm{~N}_{3} \mathrm{O}_{3} \mathrm{~S}$ (461.45): C, 57.26; H, 3.93; N, 9.11; S, 6.95\%. Found: $\mathrm{C}$, 57.37; H, 4.00; N, 9.08; S, 6.63\%. (API-CI+ $\left.{ }^{+} \mathrm{m} / \mathrm{z}, \%\right): 462\left[\mathrm{M}^{+}\right]$, 446, 445, 444 (100), 252, 225, 223, 208, 79.

1-(a,a-diphenyl-a-hydroxy)acetyl-4-cyclohexylmethylthiosemicarbazide (2e): White crystals, yield 94\%, mp 194-196 ${ }^{\circ} \mathrm{C}$; IR ( $\left.\mathrm{v}_{\max }, \mathrm{cm}^{-1}\right)$ : $3162(\mathrm{NH}), 1687$ (C=O), $1294(\mathrm{C}=\mathrm{S}) .{ }^{1} \mathrm{H}$ NMR (400 MHz, DMSO- $\left.d_{6}\right) \delta$ (ppm): 0.65-1.84 (11H, m,cyclohexyl), $3.28\left(2 \mathrm{H}, \mathrm{m},-\mathrm{CH}_{2}\right), 6.76(1 \mathrm{H}, \mathrm{s}, \mathrm{OH}), 7.09-7.59(11 \mathrm{H}, \mathrm{m}, \mathrm{Ar}-\mathrm{H}$ and $\left.\mathrm{N}^{4}-\mathrm{H}\right), 9.34\left(1 \mathrm{H}, \mathrm{s}, \mathrm{N}^{2}-\mathrm{H}\right), 10.26\left(1 \mathrm{H}, \mathrm{s}, \mathrm{N}^{1}-\mathrm{H}\right)$. Anal. Calcd for $\mathrm{C}_{22} \mathrm{H}_{27} \mathrm{~N}_{3} \mathrm{O}_{2} \mathrm{~S}$ (397.53): C, 66.47; $\mathrm{H}, 6.85 ; \mathrm{N}, 10.57 ; \mathrm{S}, 8.07 \%$. Found: C, 66.32; H, 6.84; N, 10.51; S, 8.04\%. (API-ES ${ }^{+}, \mathrm{m} / \mathrm{z}, \%$ ): $398\left[\mathrm{M}^{+}\right], 381,342,304,292,264,263,225,208,188,173$.

1-(a,a-diphenyl-a-hydroxy)acetyl-4-(3-pyridyl)thiosemicarbazide (2f): White crystals, yield $85 \%$, mp $184-186^{\circ} \mathrm{C}$; IR ( $\mathrm{v}_{\max }$ $\mathrm{cm}^{-1}$ ): $3182(\mathrm{NH}), 1651$ (C=O), 1257 (C=S). ${ }^{1} \mathrm{H}$ NMR (400 MHz, DMSO- $\left.d_{6}\right) \delta$ (ppm): $6.75(1 \mathrm{H}, \mathrm{s}, \mathrm{OH}), 7.17-7.38$ ve $7.45-7.60$ $(10 \mathrm{H}, \mathrm{m}, \mathrm{Ar}-\mathrm{H}), 7.40(1 \mathrm{H}, \mathrm{dd}, \mathrm{J}=8.07 \mathrm{~Hz}, 8.08 \mathrm{~Hz}$, pyridine- $\mathrm{H} 5)$, $7.93(1 \mathrm{H}, \mathrm{d}$, pyridine- $\mathrm{H} 4), 8.36(1 \mathrm{H}, \mathrm{d}$, pyridine- $\mathrm{H} 6), 8.53(1 \mathrm{H}$, s, pyridine-H2) $9.33\left(1 \mathrm{H}, \mathrm{N}^{4}-\mathrm{H}\right), 10.02\left(1 \mathrm{H}, \mathrm{s}, \mathrm{N}^{2}-\mathrm{H}\right), 10.56(1 \mathrm{H}$, $\mathrm{s}, \mathrm{N}^{1}-\mathrm{H}$ ). Anal. Calcd for $\mathrm{C}_{20} \mathrm{H}_{18} \mathrm{~N}_{4} \mathrm{O}_{2} \mathrm{~S}$ (378.44): C, 63.47; $\mathrm{H}$, 4.79; N, 14.80; S, 8.47\%. Found: C, 63.26; H, 4.83; N, 14.58; S, 8.15\%. (API-CI $\left.{ }^{+}, \mathrm{m} / \mathrm{z}, \%\right): 379\left[\mathrm{M}^{+}\right](100), 243,226,225,197$, 139, 138, 137.

1-(a,a-diphenyl-a-hydroxy)acetyl-4-(3,5-bistrifluoromethylphenyl)thiosemicarbazide (2g): White crystals, yield $29 \%, \mathrm{mp}$ 166-168 ${ }^{\circ} \mathrm{C}$; IR ( $\left.\mathrm{v}_{\max }, \mathrm{cm}^{-1}\right): 3252$ and $3186(\mathrm{NH}), 1651(\mathrm{C}=\mathrm{O})$, $1273(\mathrm{C}=\mathrm{S}) .{ }^{1} \mathrm{H}$ NMR $\left(400 \mathrm{MHz}, \mathrm{DMSO}-d_{6}\right) \delta(\mathrm{ppm}): 6.79(1 \mathrm{H}$, s, OH), 7.22-7.75 (10H, m, Ar-H), $7.88(1 \mathrm{H}, \mathrm{s}, \mathrm{Ar}-\mathrm{H} 4), 8.26(2 \mathrm{H}$, s, Ar-H2, Ar-H6), 9.64 (1H, s, N2-H), 10.27 (1H, s, N1-H), 10.55 $\left(1 \mathrm{H}, \mathrm{N}^{4}-\mathrm{H}\right)$. Anal. Calcd for $\mathrm{C}_{23} \mathrm{H}_{17} \mathrm{~F}_{6} \mathrm{~N}_{3} \mathrm{O}_{2} \mathrm{~S}$ (513.45): C, 53.80; H, 3.34; N, 8.18; S, 6.24\%. Found: C, 54.44; H, 3.39; N, 8.29; S, 6.24\%. (APCI- m/z, \%): $512\left(\mathrm{M}^{+}-\mathrm{H}\right)^{+}, 511$ (100), 286, 252.

1-(a,a-diphenyl-a-hydroxy)acetyl-4-(2-chloro-5-trifluoromethylphenyl)thiosemicarbazide (2h): White crystals, yield $58 \%$, mp 152-154 ${ }^{\circ} \mathrm{C}$; IR ( $\left.\mathrm{v}_{\max }, \mathrm{cm}^{-1}\right): 3302$ and $3180(\mathrm{NH}), 1693$ $(\mathrm{C}=\mathrm{O}), 1261(\mathrm{C}=\mathrm{S}) .{ }^{1} \mathrm{H}$ NMR $\left(400 \mathrm{MHz}, \mathrm{DMSO}-d_{6}\right) \delta(\mathrm{ppm})$ $6.65(1 \mathrm{H}, \mathrm{s}, \mathrm{OH}), 7.27-7.86(13 \mathrm{H}, \mathrm{m}, \mathrm{Ar}-\mathrm{H}), 10.75\left(1 \mathrm{H}, \mathrm{N}^{4}-\mathrm{H}\right)$, 
$9.06\left(1 \mathrm{H}, \mathrm{s}, \mathrm{N}^{2}-\mathrm{H}\right), 10.09\left(1 \mathrm{H}, \mathrm{s}, \mathrm{N}^{1}-\mathrm{H}\right)$. Anal. Calcd for $\mathrm{C}_{22} \mathrm{H}_{17} \mathrm{ClF}_{3} \mathrm{~N}_{3} \mathrm{O}_{2} \mathrm{~S}$ (479.90): C, 55.06; H, 3.57; N, 8.76; S, 6.68\%. Found: C, 55.21; H, 3.58; N, 8.72; S, 6.82\%.

\section{1-(a,a-diphenyl-a-hydroxy)acetyl-4-(2-trifluoromethyl-} phenyl)thiosemicarbazide (2i): White crystals, yield $64 \%, \mathrm{mp}$ 168-170 ${ }^{\circ} \mathrm{C}$; IR ( $\left.\mathrm{v}_{\max }, \mathrm{cm}^{-1}\right): 3271$ and $3194(\mathrm{NH}), 1651(\mathrm{C}=\mathrm{O})$, $1278(\mathrm{C}=\mathrm{S}) .{ }^{1} \mathrm{H}$ NMR $\left(400 \mathrm{MHz}, \mathrm{DMSO}-d_{6}\right) \delta(\mathrm{ppm}): 6.64(1 \mathrm{H}$, s, OH), 7.14-7.82 (14H, m, Ar-H), $9.02\left(1 \mathrm{H}, \mathrm{N}^{4}-\mathrm{H}\right), 9.94(1 \mathrm{H}, \mathrm{s}$, $\left.\mathrm{N}^{2}-\mathrm{H}\right), 10.55\left(1 \mathrm{H}, \mathrm{s}, \mathrm{N}^{1}-\mathrm{H}\right)$. Anal. Calcd for $\mathrm{C}_{22} \mathrm{H}_{18} \mathrm{~F}_{3} \mathrm{~N}_{3} \mathrm{O}_{2} \mathrm{~S}$ (445.45): C, 59.32; H, 4.07; N, 9.43; S, 7.20\%. Found: C, 58.36; H, $4.51 ; \mathrm{N}, 8.73 ; \mathrm{S}, 6.80 \%$. (API-ES $\left.{ }^{+}, \mathrm{m} / \mathrm{z}, \%\right): 446\left[\mathrm{M}^{+}\right](100), 428$, 368, 302, 296, 279, 257, 225, 192.

\section{1-(a,a-diphenyl-a-hydroxy)acetyl-4-(2-methylsulphanyl-} phenyl)thiosemicarbazide (2j): White crystals, yield $63 \%, \mathrm{mp}$ 164-166 ${ }^{\circ} \mathrm{C}$; IR ( $\left.\mathrm{v}_{\max }, \mathrm{cm}^{-1}\right)$ : 3325 and $3261(\mathrm{NH}), 1651(\mathrm{C}=\mathrm{O})$, $1255(\mathrm{C}=\mathrm{S}) .{ }^{1} \mathrm{H}$ NMR $\left(400 \mathrm{MHz}, \mathrm{DMSO}-d_{6}\right) \delta(\mathrm{ppm}): 2.34(3 \mathrm{H}$, s, S-CH $)_{3}, 6.72(1 \mathrm{H}, \mathrm{s}, \mathrm{OH}), 7.11-7.60(14 \mathrm{H}, \mathrm{m}, \mathrm{Ar}-\mathrm{H}), 9.00(1 \mathrm{H}$, $\left.\mathrm{N}^{4}-\mathrm{H}\right), 9.82\left(1 \mathrm{H}, \mathrm{s}, \mathrm{N}^{2}-\mathrm{H}\right), 10.53\left(1 \mathrm{H}, \mathrm{s}, \mathrm{N}^{1}-\mathrm{H}\right)$. Anal. Calcd for $\mathrm{C}_{22} \mathrm{H}_{21} \mathrm{~N}_{3} \mathrm{O}_{2} \mathrm{~S}_{2}$ (423.55): C, 62.39; $\mathrm{H}, 5.00 ; \mathrm{N}, 9.92 ; \mathrm{S}, 15.14 \%$. Found: C, 62.21; H, 4.93; N, 9.89; S, 14.92\%.

1-(a,a-diphenyl-a-hydroxy)acetyl-4-(1-adamantyl)thiosemicarbazide (2k): White crystals, yield 83\%, mp 160-162 ${ }^{\circ} \mathrm{C}$; IR $\left(\mathrm{v}_{\max }, \mathrm{cm}^{-1}\right): 3313$ and $3180(\mathrm{NH}), 1651(\mathrm{C}=\mathrm{O}), 1282(\mathrm{C}=\mathrm{S}) \cdot{ }^{1} \mathrm{H}$ NMR (400 MHz, DMSO- $\left.d_{6}\right) \delta$ (ppm): $1.06\left(3 \mathrm{H}, \mathrm{t},-\mathrm{CH}_{3}\right.$ of ethanol), 1,48-2.59 (16H, m, adamantyl-H), 3.40-3.53 (2H, m, $-\mathrm{CH}_{2}$ of ethanol), $4.36\left(1 \mathrm{H}, \mathrm{t}, \mathrm{OH}\right.$ of ethanol), $6.12\left(1 \mathrm{H}, \mathrm{N}^{4}-\mathrm{H}\right), 6.92$ $(1 \mathrm{H}, \mathrm{s}, \mathrm{OH}), 7.23-7.48$ (10H, m, Ar-H), $9.13\left(1 \mathrm{H}, \mathrm{s}, \mathrm{N}^{2}-\mathrm{H}\right), 10.26$ $\left(1 \mathrm{H}, \mathrm{s}, \mathrm{N}^{1}-\mathrm{H}\right) .{ }^{13} \mathrm{C}$ NMR (100 MHz, DMSO-d $\left.{ }_{6}\right) \delta$ (ppm): 19.21, 29.64, 36.58, 39.51, 39.72, 39.93, 40.14, 40.35, 40.55, 40.77, 41.54 (adamantyl), 53.68 (solvent), 56.76 (NH-adamantyl carbon), 81.05 (C-OH), 128.10, 128.32 (Ar), 144.21 (C=O), $180.00(\mathrm{C}=\mathrm{S})$. Anal. Calcd for $\mathrm{C}_{25} \mathrm{H}_{29} \mathrm{~N}_{3} \mathrm{O}_{2} \mathrm{~S}_{2} \mathrm{C}_{2} \mathrm{H}_{5} \mathrm{OH}$ (481.65): C, 67.33; $\mathrm{H}$, 7.32; N, 8.72; S, 6.66\%. Found: C, 67.14; H, 7.07; N, 8.79; S, 6.51\%. (API-CI $\left.{ }^{+}, \mathrm{m} / \mathrm{z}, \%\right): 436\left[\mathrm{M}^{+}\right](100), 418,226,225,243$.

General procedure for the synthesis of [5-(substitutedamino)1,3,4-thiadiazole-2-yl](diphenyl)methanol (3a-b)

A sample of corresponding 1,4-disubstituted-thiosemicarbazides $(0.001 \mathrm{~mol})$ was treated with concentrated sulphuric acid at room temperature with constant stirring for 1-2 $\mathrm{h}$. The reaction mixture was poured into ice water. The product was precipitated, filtered and washed with water to afford $\mathbf{3 a - b}$ in quantitative yield.

[5-(ethenylamino)-1,3,4-thiadiazole-2-yl](diphenyl)methanol (3a): White powder, yield 81\%, mp 202-203 oC; IR (vmax, cm1): $3257(\mathrm{NH}), 1614(\mathrm{C}=\mathrm{N})$. 1H NMR (400 MHz, DMSO-d6) $\delta$ (ppm): $3.66(\mathrm{t}, 2 \mathrm{H},=\mathrm{CH} 2, \mathrm{~J}=6.86 \mathrm{~Hz}, 13.77 \mathrm{~Hz}), 4.76(\mathrm{~s}$, $1 \mathrm{H}, \mathrm{OH}), 6.79$ (d, 1H, $-\mathrm{CH}=, \mathrm{J}=7.70 \mathrm{~Hz}), 6.93-7.42(\mathrm{~m}, 10 \mathrm{H}$, ArH), 7.81 ve 8.18 (2s, 1H, NH). Anal. Calcd for C17H15N3OS (309.38): C, 66.00; H, 4.89; N, 13.58; S, 10.36\%. Found: C, 65.12; $\mathrm{H}, 4.86 ; \mathrm{N}, 13.11 ; \mathrm{S}, 10.13 \%$. (API-ES+, m/z, \%): 310 [M+] (100), $256,208,192$

[5-(benzoylamino)-1,3,4-thiadiazole-2-yl](diphenyl)methanol (3b): Yellow crystals, yield 87\%, mp 206-208 ${ }^{\circ} \mathrm{C}$; IR $\left(\mathrm{v}_{\max }, \mathrm{cm}^{-1}\right)$ : 3250 and $3165(\mathrm{NH}), 1600(\mathrm{C}=\mathrm{N}) .{ }^{1} \mathrm{H}$ NMR $\left(400 \mathrm{MHz}, \mathrm{DMSO}-d_{6}\right)$ $\delta$ (ppm): 7.04-8.17 (m,16 H, ArH ve OH), 12.44 (s, 1H, -NHCO). Anal. Calcd for $\mathrm{C}_{22} \mathrm{H}_{17} \mathrm{~N}_{3} \mathrm{O}_{2} \mathrm{~S}$ (387.45): C, 68.20; $\mathrm{H}, 4.42 ; \mathrm{N}, 10.85$; S, 8.28\%. Found: C, 68.20; H, 4.61; N, 10.91; S, 8.90\%.
General procedure for the synthesis of 3-[hydroxy(diphenyl) methyl]-4-(nonsusbtituted/substituted)-2,4-dihydro-5H1,2,4-triazole-5-thione (4a-c)

Sodium hydroxide $(2 \mathrm{~N}, 15-20 \mathrm{~mL})$ was added to corresponding 1,4-disubstituted-thiosemicarbazides and refluxed on water bath for $4 \mathrm{~h}$. The reaction mixture was neutralized with hydrochloric acid (10\%). The precipitate was filtered, washed with water and crystallized from ethanol.

3-[hydroxy(diphenyl)methyl]-2,4-dihydro-5H-1,2,4-triazole5-thione (4a): White crystals, yield $49 \%, \operatorname{mp} 258{ }^{\circ} \mathrm{C}$; IR ( $\mathrm{v}_{\max }$ $\left.\mathrm{cm}^{-1}\right)$ : 3107 (NH), 1577, 1487 (C=N, NH), 1260 (C-N), 1180 $(\mathrm{C}=\mathrm{S}),{ }^{1} \mathrm{H}$ NMR $\left(400 \mathrm{MHz}, \mathrm{DMSO}-d_{6}\right) \delta$ (ppm): $6.95(1 \mathrm{H}, \mathrm{s}$, $\mathrm{OH})$, 7.11-7.58 (10H, m, Ar-H), 13.20 (1H, s, NH), 13.40 (1H, s, $\mathrm{NH})$. Anal. Calcd for $\mathrm{C}_{15} \mathrm{H}_{13} \mathrm{~N}_{3} \mathrm{OS} .1 / 2 \mathrm{H}_{2} \mathrm{O}$ (292.35): C, 61.62; H, 4.83; N, 14.37; S, 10.97\%. Found: C, 60.97; H, 4.60; N, 13.84; S, $10.64 \%$.

\section{3-[hydroxy(diphenyl)methyl]-4-[4-(trifluoromethoxy)} phenyl]-2,4-dihydro-5H-1,2,4-triazole-5-thione (4b): White crystals, yield $84 \%, \mathrm{mp} 235-237{ }^{\circ} \mathrm{C}$; IR $\left(\mathrm{v}_{\max }, \mathrm{cm}^{-1}\right): 3169(\mathrm{NH})$, 1510, 1558 (C=N, NH), 1271 (C-N), 1155 (C=S). ${ }^{1} \mathrm{H}$ NMR (400 $\left.\mathrm{MHz}, \mathrm{DMSO}-d_{6}\right) \delta$ (ppm): $6.91(2 \mathrm{H}, \mathrm{d}, \mathrm{Ar}-\mathrm{H}, J=8.9 \mathrm{~Hz}), 7.00$ $(1 \mathrm{H}, \mathrm{s}, \mathrm{OH}), 7.15(2 \mathrm{H}, \mathrm{d}, \mathrm{Ar}-\mathrm{H}, \mathrm{J}=8.2 \mathrm{~Hz}), 7.18-7.35(10 \mathrm{H}, \mathrm{m}$, Ar-H), 13.49 (1H, s, NH). Anal. Calcd for $\mathrm{C}_{22} \mathrm{H}_{16} \mathrm{~F}_{3} \mathrm{~N}_{3} \mathrm{O}_{2} \mathrm{~S} \cdot \mathrm{H}_{2} \mathrm{O}$ (461.46): C, 57.26; H, 3.93; N, 9.11; S, 6.95\%. Found: C, 58.04; H, 4.03; N, 9.05; S, 6.34\%. (API-ES $\left.{ }^{+}, \mathrm{m} / \mathrm{z}, \%\right): 444\left[\mathrm{M}^{+}\right], 443,426$, $425,388,314,261,79$.

\section{4-[3,5-bis(trifluoromethyl)phenyl)]-3-[hydroxy(dipenyl)} methyl]-2,4-dihydro-5H-1,2,4-triazole-5-thione (4c): White crystals, yield $78 \%, \mathrm{mp} 215-216{ }^{\circ} \mathrm{C}$; IR $\left(\mathrm{v}_{\max }, \mathrm{cm}^{-1}\right): 3365(\mathrm{NH})$, 1556, 1492 (C=N, NH),1276 (C-N), 1120 (C=S). ${ }^{1} \mathrm{H}$ NMR (400 MHz, DMSO- $\left.d_{6}\right) \delta$ (ppm): $7.12(1 \mathrm{H}, \mathrm{s}, \mathrm{OH}), 7.18-7.34(10 \mathrm{H}, \mathrm{m}$, $\mathrm{Ar}-\mathrm{H}), 7.52\left(2 \mathrm{H}\right.$, s, triazole $\left.\mathrm{ArC}_{2}-\mathrm{H}, \mathrm{ArC}_{6}-\mathrm{H}\right), 8.07(1 \mathrm{H}$, s, triazole $\left.\mathrm{ArC}_{4}-\mathrm{H}\right), 14.14(1 \mathrm{H}, \mathrm{s}, \mathrm{NH})$. Anal. Calcd for $\mathrm{C}_{23} \mathrm{H}_{15} \mathrm{~F}_{6} \mathrm{~N}_{3} \mathrm{OS}$ (495.44): C, 55.76; H, 3.05; N, 8.48; S, 6.47\%. Found: C, 55.86; H, $2.86 ; \mathrm{N}, 8.55 ; \mathrm{S}, 6.19 \%$.

\section{Cytotoxic Activity}

The synthesized compounds were tested for their cytotoxic activities. Cell viability and cytotoxic activity profile of the compounds were analyzed using the Cell Proliferation Kit I (MTT) [Roche, Germany]. MTT [3-(4,5-dimethylthiazole-2-yl)-2,5diphenyltetrazolium bromide] is cleaved to formazan crystals by the "succinate-tetrazolium reductase" system which belongs to the mitochondrial respiratory chain and is active only in viable cells (37-38). HEK293 cell line was used for the determination of cytotoxic activity. The MTT metabolic assay was carried out in 96-well flat-bottom cell culture plates seeded with 5x103 cells/well. HEK293 cells in $100 \mathrm{mM}$ containing LGlutamine without antibiotic Eagle's MEM (Minimum Essential Medium) and RPMI 1640MEM with 10\% FBS (Fetal Bovine Serum).

The following day, media was aspirated and the compounds were solved in DMSO and diluted with medium before they were added to the cell cultures at the concentrations of $5.0 \mu \mathrm{g} /$ $\mathrm{mL}$ and $10.0 \mu \mathrm{g} / \mathrm{mL}$. Cells were incubated for $48 \mathrm{hrs}$ at $37^{\circ} \mathrm{C}$, $5.0 \% \mathrm{CO}_{2}$. After the incubation period add $10 \mu \mathrm{L}$ of the MTT labeling reagent (final concentration $0.5 \mathrm{mg} / \mathrm{mL}$ ) to each well. Incubate the microplate for $4-12$ hrs in a humidified atmos- 


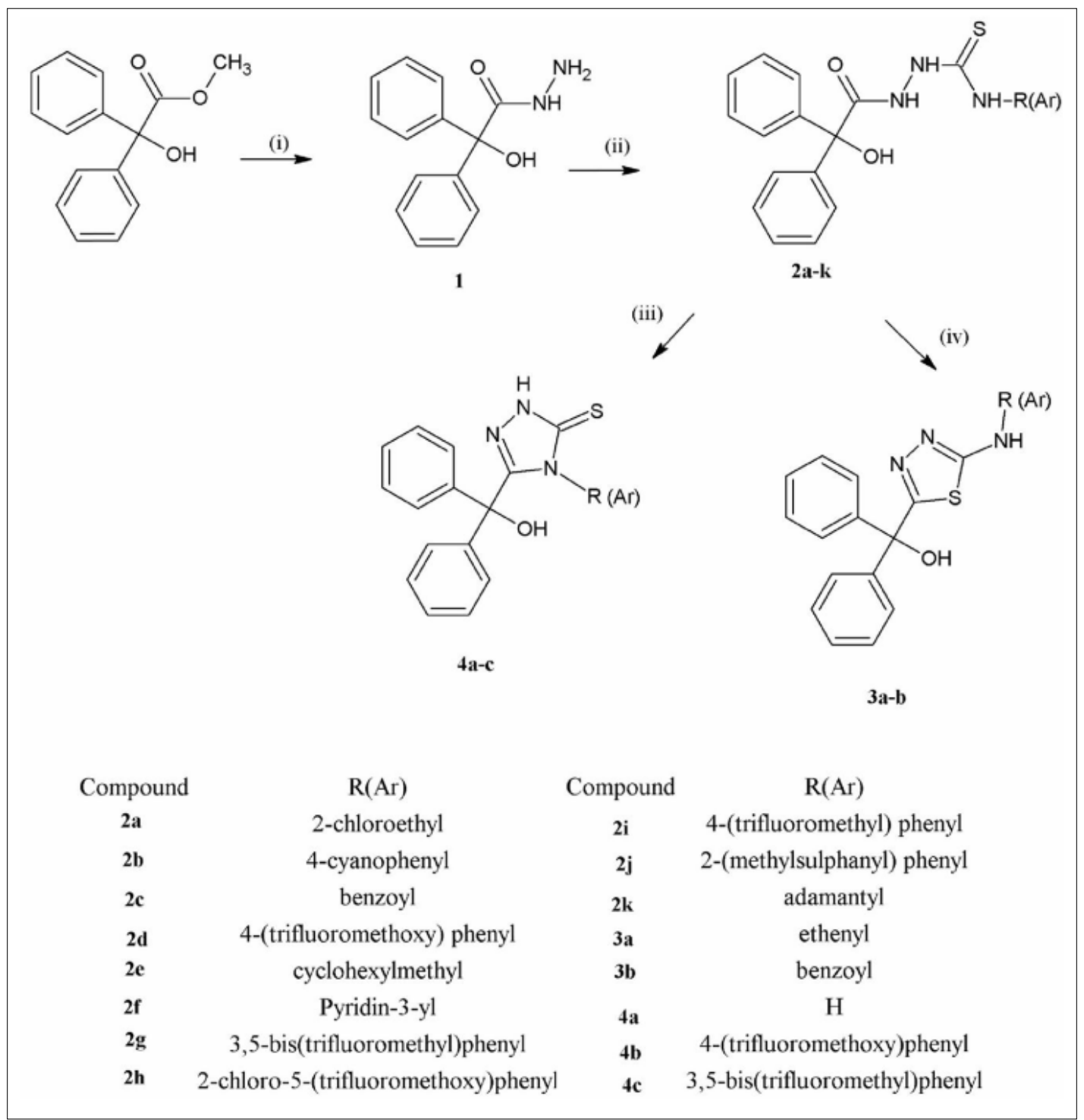

Scheme 1. Reactions and conditions; (i) hydrazine hydrate; (ii) (Ar)R-N=C=S; (iii) $2 \mathrm{~N} \mathrm{NaOH}, 10 \% \mathrm{HCl}$; (iv) concentrated $\mathrm{H}_{2} \mathrm{SO}_{4}$, room temperature.

phere (e.g. $37{ }^{\circ} \mathrm{C}, 5.0 \% \mathrm{CO}_{2}$ ) and add $100 \mu \mathrm{L}$ of the solubilization solution into each well. Allow the plate to stand overnight in the incubator in a humidified atmosphere (e.g. $37^{\circ} \mathrm{C}, 5.0 \%$ $\mathrm{CO}_{2}$ ), the formazan crystals solubilized. Absorbance of formazan product was measured with spectrophotometrically at 550 and $690 \mathrm{~nm}$.

\section{RESULTS AND DISCUSSION}

In this research, 1-(a,a-diphenyl-a-hydroxy)acetyl-4-substitutedthiosemicarbazide (2a-k), [5-(substitutedamino)-1,3,4-thiadiazole-2-yl](diphenyl)methanol (3a-b) and 3-[hydroxy(diphenyl)methyl]-4-(nonsusbtituted/ substituted)-2,4-dihydro-5H-1,2,4-triazole-5-thione derivatives $(\mathbf{4 a - c})$ were synthesized. In the first part of the study, benzilic acid methyl ester was reacted with hydrazine hydrate in absolute ethanol to afford benzilic acid hydrazide (1). Reaction of $\mathbf{1}$ with appropriate alkyl/arylisothiocyanates gave 1-(a,adiphenyl-a-hydroxy)acetyl-4-(substituted)thiosemicarbazide (2a-k). [5-(Substitutedamino)-1,3,4-thiadiazole-2-yl](diphenyl) methanol derivatives (3a-b) were obtained by cyclization of $\mathbf{2 a}$ and $2 \mathrm{c}$ with concentrated sulphuric acid. On the other hand, 3-[hydroxy(diphenyl)methyl]-4-(nonsusbtituted/ substituted)-2,4-dihydro-5H-1,2,4-triazole-5-thione were obtained by cyclization of $\mathbf{2} \mathbf{c}, \mathbf{2} \mathbf{d}$ and $\mathbf{2} \mathbf{g}$ with $\mathrm{NaOH}(2 \mathrm{~N})$ (Scheme 1). During the cyclization of 2a, 2-chloroethyl group converted to ethenyl group in the acidic media. Unexpectedly, $\mathbf{4 a}$ was obtained from the cyclization reaction of $\mathbf{2} \mathbf{c}$ by missing the benzoyl group. Ergenç et. al. (39) reported different methodology for the synthesis of the compound 4a therefore it was necessary to elucidate the structure of this compound.

The preference formation of the 1,3,4-thiadiazole ring under acidic condition can be due to the loss of nucleophilicity of N-4 as a result of its protonation leading to a comparable increase in the nucleophilicity of the sulphur atom towards the attack of the carbonyl carbon. On the other hand, when cyclization 


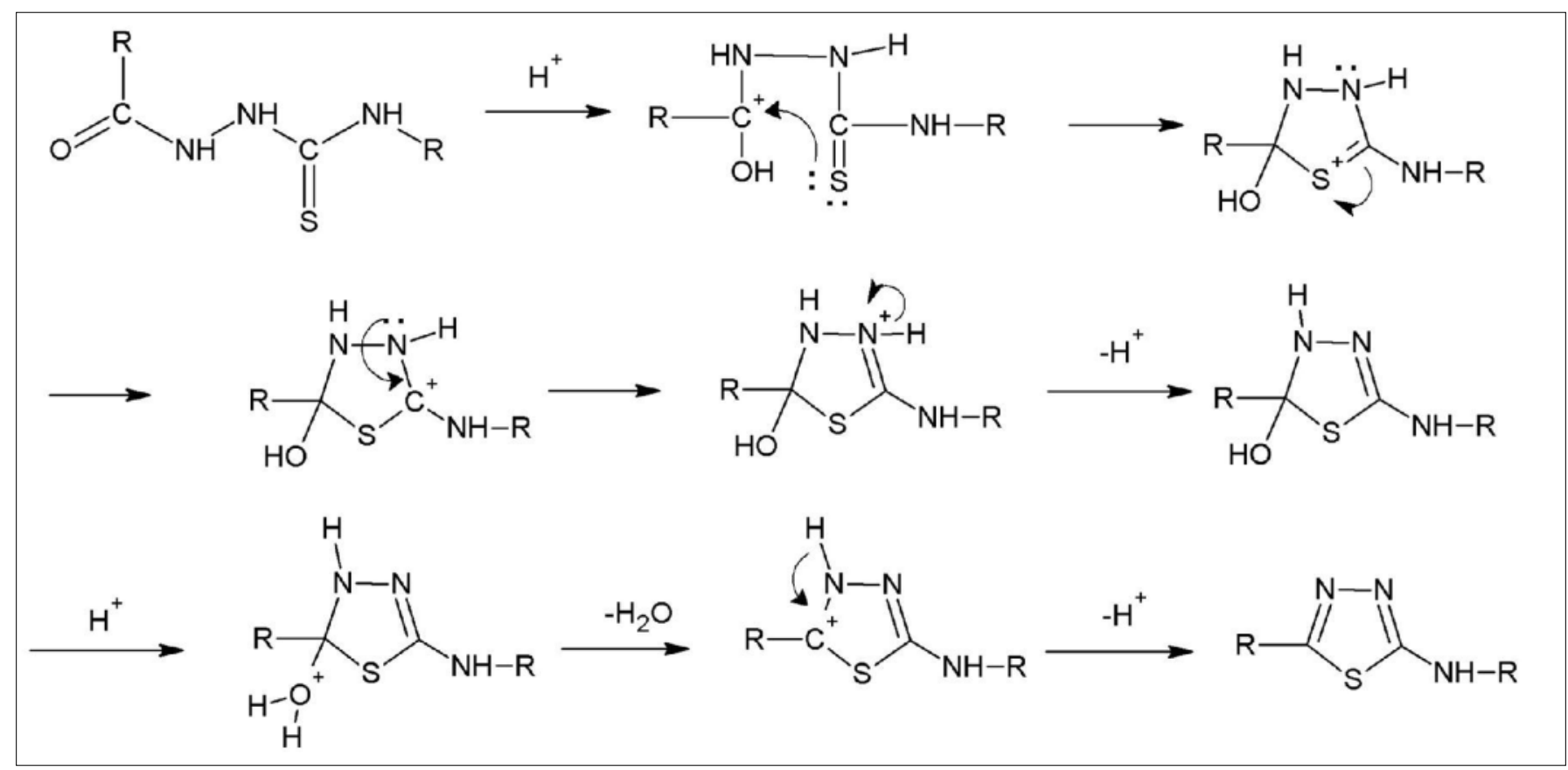

Scheme 2. Proposed mechanism for the synthesis of 2,5-disubstituted-1,3,4-thiadiazoles.

was carried out under alkaline conditions, the nucleophilicity of N-4 was enhanced and led to cyclization the carbonyl carbon atom to give 1,2,4-triazole-5-thiones. Because of the alkaline media, the nitrogen atom of acylthiosemicarbazides is more nucleophilic than either the oxygen of the carbonyl group or the sulphur of the thiocarbonyl group. The reaction mechanism of 1,3,4-thiadiazole derivatives (3a-b) is shown in Scheme 2 and a possible mechanism for the synthesis of 1,2,4-triazole-5-thiones (4a-c) is shown in Scheme $3(40,41)$.

All the synthesized compounds have been characterized by means of both analytical and spectroscopic methods. The IR spectra of the 1,4-disubstituted thiosemicarbazide derivatives (2a-k) have $\mathrm{C}=\mathrm{O}$ stretching bands at $1651-1707 \mathrm{~cm}^{-1}$ and $\mathrm{C}=\mathrm{S}$ bands at $1244-1294 \mathrm{~cm}^{-1}$. The ${ }^{1} \mathrm{H}-\mathrm{NMR}$ spectra of compounds 2a-k showed signals at 10.09-13.17, 9.06-11.93 and 6.12-10.86 ppm, attributed to $\mathrm{N}^{1} \mathrm{H}, \mathrm{N}^{2} \mathrm{H}$ and $\mathrm{N}^{4} \mathrm{H}-\mathrm{Ar}(\mathrm{R})$, respectively (42). On the other hand, ${ }^{13} \mathrm{C}-\mathrm{NMR}$ spectra of the compound $2 \mathrm{k}$ exhibited resonance at 180.00 and $144.21 \mathrm{ppm}$ assigned for $\mathrm{C}=\mathrm{S}$ and $\mathrm{C}=\mathrm{O}$ moieties, respectively. For compounds $4 \mathrm{a}-\mathrm{c}$ the IR spectra showed bands around $1120-1180 \mathrm{~cm}^{-1}$ characteristics for $C=S$ bending vibrations and around $1260-1276 \mathrm{~cm}^{-1}$ characteristics for $\mathrm{C}-\mathrm{N}$ vibrations, providing evidence for ring closure. In the IR spectra of compounds $3 \mathbf{a}-\mathbf{b}$ and $4 \mathbf{a}-\mathbf{c}$ no absorption bands were detected about $1651-1707 \mathrm{~cm}^{-1}$ indicating the absence $\mathrm{C}=\mathrm{O}$ group of compounds $\mathbf{2} \mathbf{a}-\mathbf{k}$ which is an evidence for the conversion of thiosemicarbazides to thiadiazoles and triazoles. From cyclization of compounds 2a-k under alkaline conditions, only the thione type compounds 4a-c were observed by the presence of absorption maxima at 1120-1180 $\mathrm{cm}^{-1}$ belonging to $\mathrm{C}=\mathrm{S}$ group. (43). The ${ }^{1} \mathrm{H}-\mathrm{NMR}$ (DMSO- $d_{6}$ ) spectrum of compound $3 \mathbf{b}$ displayed $\mathrm{NH}$ resonance in 12.44 ppm (44). Further structural confirmation was provided by the HSQC spectrum of compound 3a which showed the expected ${ }^{13} \mathrm{C}_{-1}{ }^{\mathrm{H}} \mathrm{H}$ correlations. $\left(\mathrm{M}^{+}-\mathrm{H}\right)^{-}$ions with $100 \%$ abundance ob-

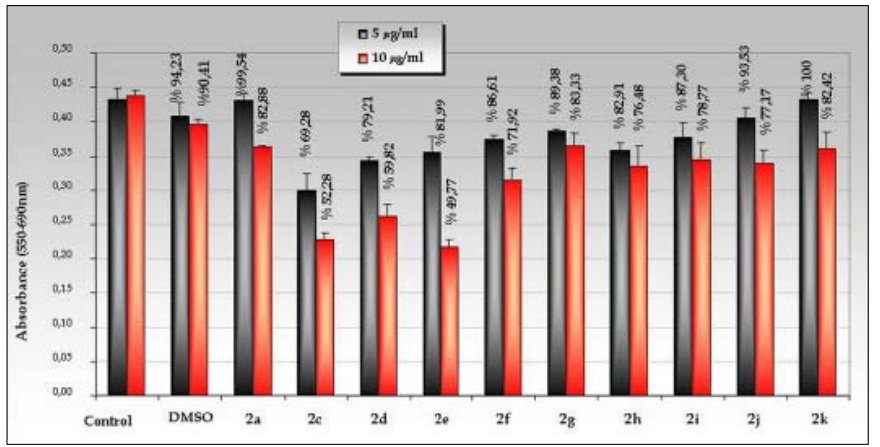

Figure 1. Absorbance values of after MTT assay formazan crystalls of 1,4-disubstituted thiosemicarbazides.

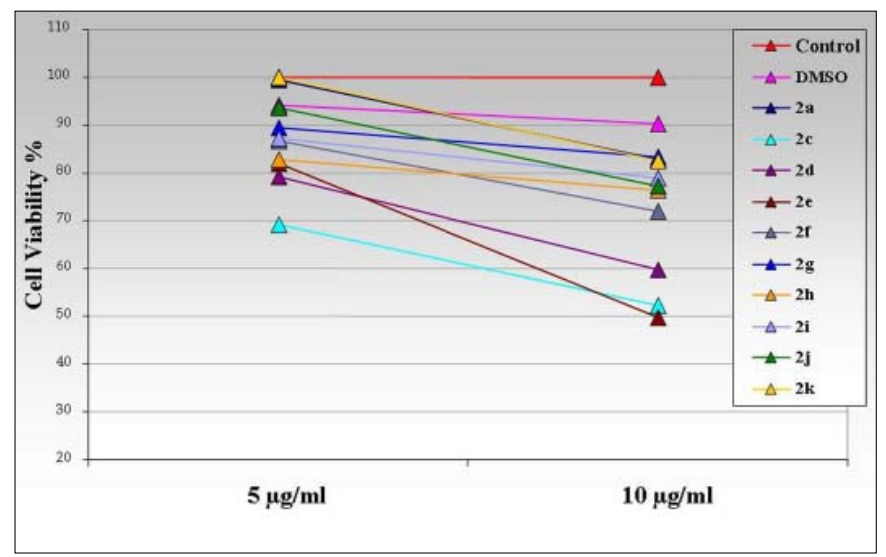

Figure 2. Cell viability (\%) of compounds $\mathbf{2 a}$, 2c-k.

served in the atmospheric pressure chemical ionization [APCI] was spectra of compound $\mathbf{2 g},\left[\mathrm{M}^{+}\right]$ions observed in [API-ES $\left.{ }^{+}\right]$ 


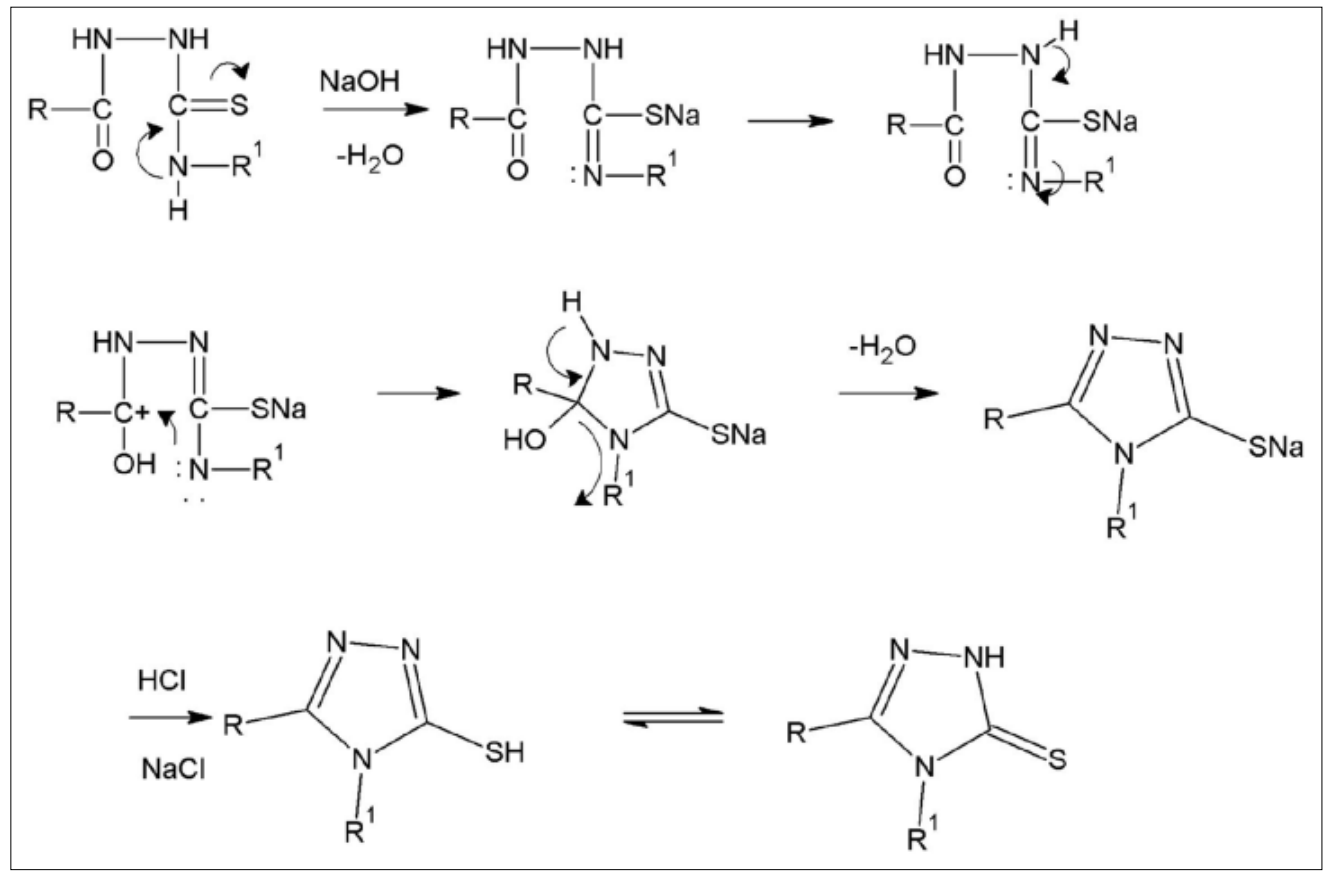

Scheme 3. Proposed mechanism for the synthesis of 1,2,4-triazole-5-thiones.

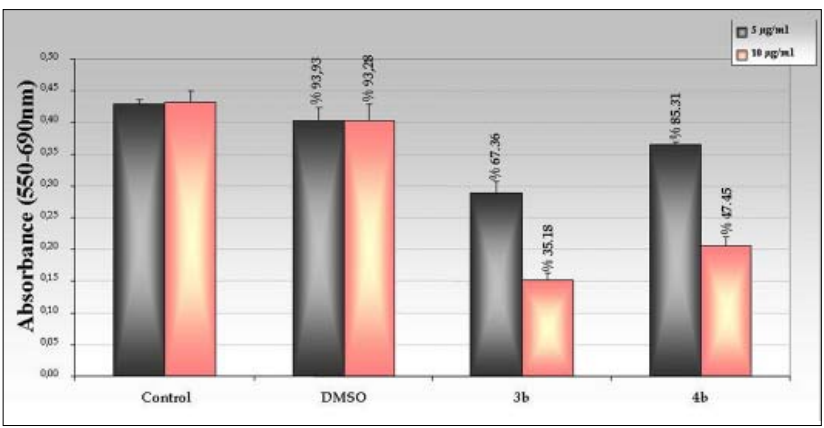

Figure 3. Absorbance values of after MTT assay formazan crystalls of thiadiazole and triazoles.

and $\left[\mathrm{API}-\mathrm{CI}^{+}\right]$were spectra of compounds $\mathbf{2 a - f}, \mathbf{2} \mathbf{i}, \mathbf{2 k}, \mathbf{3 a}, \mathbf{4} \mathbf{b}$ provided further confirmation for the formation of the expected structures. Mass spectra of these compounds gave molecular ion peaks except compound $\mathbf{2 a}$, however, with different intensities. Because of the loss of $\mathrm{H}_{2} \mathrm{O}$ and isothiocyanate molecules, the major fragmentation pathway in the 1,4-disustituted thiosemicarbazide derivatives formation of $\mathrm{C}_{14} \mathrm{H}_{11} \mathrm{NO}_{2}+$ $(\mathrm{m} / \mathrm{z} 225)$ ion is observed. Besides, some compounds undergo specific fragmentations.

Cytotoxicity of the selected compounds were evaluated by using HEK293 cell line according to procedures of MTT [3-(4,5-dimethylthiazole-2-yl)-2,5-diphenyltetrazolium bromide] assay. All the compounds were dissolved in dimethylsulfoxide $(2.5 \%)$ and no cytotoxic effect on the cells was observed when compared to the control group. $5.0 \mu \mathrm{g} / \mathrm{mL}$ and $10.0 \mu \mathrm{g} / \mathrm{mL}$ were used in two different doses and dose-dependent cytotoxic activity was investigated. Cell viability and cytotoxic activity profile of the compounds were analyzed using the MTT assay.

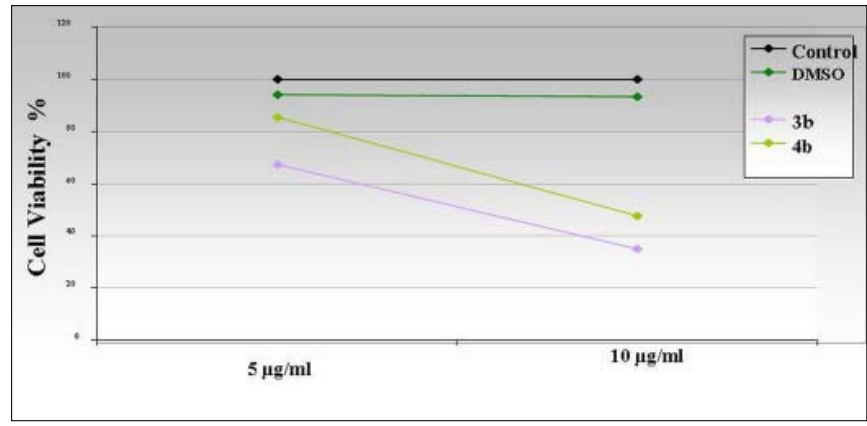

Figure 4. Cell viability (\%) of compounds $3 b$ and $4 b$.

Cytotoxic activity results were presented in Figures 1-4. The cytotoxic activity range of 1,4-disubstituted-thiosemicarbazides is $0-30.72 \%$ at $5.0 \mu \mathrm{g} / \mathrm{mL}$ concentration. Even these values are below $50 \%$ for the $5.0 \mu \mathrm{g} / \mathrm{mL}$ concentrations, we could not mention about cytotoxic compounds. The cytotoxic activity range is $9.59-50.23 \%$ at $10.0 \mu \mathrm{g} / \mathrm{mL}$ concentration. Based on the gained data 4 compounds which belong to our set of ten 1,4-disubstituted thiosemicarbazide derivatives demonstrated inhibition between $5-20 \%$, the other four compounds $20-30 \%$, whereas the other two compounds demonstrated inhibition between $40-50 \%$ (Figure 1). Only one compound which have cytotoxicity with the value of $50.23 \%$ at 10.0 $\mu \mathrm{g} / \mathrm{mL}$ is $1-(\mathrm{a}, \mathrm{a}$-diphenyl-a-hydroxy)acetyl-4-cyclohexylmethylthiosemicarbazide (2e). We have also made comparison of cyctotoxic activity of thiosemicarbazides with their cyclic derivatives, thiadiazoles and triazoles (Figure 3). [5-(Benzoylamino)-1,3,4-thiadiazole-2-yl](diphenyl)methanol (3b), which is derivative of compound $2 \mathrm{c}$ and 3-[hydroxy(diphenyl)methyl]-4-[4-(trifluoromethoxy) 


\section{Benzilik asid hidrazidinden elde edilen bazı 1,4-disübstitüe tiyosemikarbazidler, 2,5-disübstitüe-} 1,3,4-tiyadiazoller ve 1,2,4-triazol-5-tiyonların sentezi ve sitotoksik aktivitelerinin değerlendirilmesi

\section{ÖZET}

Bu çalışmada 1-( $\alpha, \alpha$-difenil- $\alpha$-hidroksi)asetil-4-sübstitüetiyosemikarbazid (2a-k), [5-(sübstitüeamino) -1,3,4-tiyadiazol2-il] (difenil)metanol (3a-b) ve 3-[hidroksi(difenil)metil]-4-(nonsübstitüe/sübstitüe)-2,4-dihidro-5H-1,2,4-triazol-5tiyon (4a-c) yapısındaki yeni bileşikler sentez edilmiş ve bileşiklerin sitotoksik etkinlikleri araştırılmıştır. Bu amaçla benzilik asit metil esterinin hidrazin hidrat ile etanollü ortamda reaksiyonu ile benzilik asit hidrazidi (1) elde edilmiş, 1'in uygun alkil/aril isotiyosiyanatlara katımı ile 1-( $\alpha, \alpha$-difenil- $\alpha$-hidroksi)asetil-4-sübstitüetiyosemikarbazid (2a-k) kazanılmıştır. [5-(sübstitüeamino)-1,3,4-tiyadiazol-2-il](difenil)metanol türevi (3a-b) bileşikler, 2a ve 2c' nin derişik sülfürik asit ile siklizasyonu sonucu elde edilmiştir. 3-[hidroksi(difenil)metil]-4-(nonsübstitüe/sübstitüe)-2,4-dihidro-5H1,2,4-triazol-5-tiyon türevi (4a-c) bileşikler ise $2 \mathrm{c}$, $2 \mathrm{~d}$ ve $2 \mathrm{~g}^{\prime}$ nin $2 \mathrm{~N}$ NaOH ile reaksiyonundan kazanılmıştır. Bileşiklerin yapıları elemental analiz, HPLC, UV, IR, 1H-NMR, 13C-NMR, HSQC ve MS verileri ile doğrulanmıştır. Bileşik 2a, 2c-k, 3b ve 4b HEK293 hücre hattı kullanılarak MTT yöntemiyle sitotoksik etkinlikleri araştırmak üzere seçilmiştir. Özellikle 1-( $\alpha, \alpha$-difenil- $\alpha$-hidroksi)asetil-4-siklohekzilmetiltiyosemikarbazid (2e) bileşiğinde $10 \mathrm{mg} / \mathrm{ml}$ konsantrasyonda \% 50.23 sitotoksik aktivite saptanmıştır.

ANAHTAR KELIMELER: tiyosemikarbazid, tiyadiazol, 1,2,4-triazol-5-tiyon, sitotoksik aktivite

phenyl]-2,4-dihydro-5H-1,2,4-triazole-5-thione (4b), which is derivative of $\mathbf{2} \mathbf{d}$ have not showed any cytotoxic activity at the dose of $5.0 \mu \mathrm{g} / \mathrm{mL}$. As statistically significant results, the cytotoxic activity of the three heterocyclic compounds that were used in the synthesis, increases depending on the dose $(\mathrm{p}<0.05)$, which means they showed a dose-related effect at these concentrations.

\section{CONCLUSIONS}

A series of 1,4-disubstituted-thiosemicarbazides, 2,5-disubstituted-1,3,4-thiadiazoles and 1,2,4-triazole-5-thiones were syn- thesized and screened for their cytotoxic activities against HEK293 cell line. The cytotoxicity screening indicated that among the tested compounds 1-(a,a-diphenyl-a-hydroxy) acetyl-4-cyclohexylmethylthiosemicarbazide (2e) exhibited cytotoxic activity.

\section{ACKNOWLEDGEMENTS}

This study was financially supported by the Marmara University Scientific Research Committee (Project No: SAG-CYLP-090909-0286).

\section{REFERENCES}

1. Raman K, Singh HK, Salzman SK, Parmar SS. Substituted thiosemicarbazides and corresponding cyclized 1,3,4-oxadiazoles and their anti-inflammatory activity. J Pharm Sci 1993; 82: 167-9.

2. Cardiaa MC, Distinto $S$, Maccioni E, Plumitallo A, Saddi M, Sanna ML, DeLogu A. Isonicotinoylhydrazothiazoles and isonicotinoyl-N4-substituted thiosemicarbazides: Synthesis, characterization, and anti-mycobacterial activity. J Heterocycl Chem 2006; 43: 1337-42.

3. Küçükgüzel G, Kocatepe A, De Clercq E, Şahin F, Güllüce M. Synthesis and biological activity of 4-thiazolidinones, thiosemicarbazides derived from diflunisal hydrazide. Eur J Med Chem 2006; 41: 353-9.

4. Plech T, Wujec M, Siwek A, Kosikowska U, Malm A. Synthesis and antimicrobial activity of thiosemicarbazides. S-triazoles and their Mannich bases bearing 3-chlorophenyl moiety. Eur J Med Chem 2011; 46: 241-8.

5. Ulusoy N, Ergenc N, Sanış GO. Synthesis, characterizations and antimicrobial evaluation of new 1-acyl-4substituted thiosemicarbazide and 2,5-disubstituted 1,3,4- thidiazole derivatives. Acta Pharm Turcica 1996; 38: 111-6.
6. Doğan HN, Rollas S, Erdeniz H. Synthesis, structure elucidation and antimicrobial activity of some 3-hydroxy-2naphthoic acid hydrazide derivatives. Farmaco 1998; 53: $462-7$.

7. Kerimov I, Ayhan-Kılcıgil G, Can-Eke B, Altanlar N, İscan M. Synthesis, antifungal and antioxidant screening of some novel benzimidazole derivatives. J Enz Inhib Med Chem 2007; 22: 696-701.

8. Siwek A, Staczek P, Stefanska J. Synthesis and structureactivity relationship studies of 4-arylthiosemicarbazides as topoisomerase IV inhibitors with Gram-positive antibacterial activity. Search for molecular basis of antibacterial activity of thiosemicarbazides. Eur J Med Chem 2011; 46: 5717-26.

9. Mayekar SA, Mulwad VV. Synthesis and antibacterial activity of 6-(5-phenyl-[1,3,4] thiadiazol-ylamino)-benzopyran-2-ones. Ind J Chem 2008; 47B: 1438-42.

10. Gülerman NN, Rollas $S$, Ekinci AC, Vidin A. Anticonvulsant activity of some substituted 1,3,4-thiadiazoles. Acta Pharm Turc 2001; 43: 161-3.

11. Zou XJ, Lai LH, Jin GY, Zhang ZX. Synthesis, Fungicidal Activity, and 3D-QSAR of Pyridazinone-Substituted 1,3,4-Oxadiazoles and 1,3,4-Thiadiazoles. J Agric Food Chem 2002; 50: 3757-60. 
12. Matysiak J, Malinski Z. 2-(2,4-Dihydroxyphenyl)-1,3,4thiadiazole analogues: Antifungal activity in vitro against candida species1. Russian J Bioorg Chem 2007; 33: 594-601.

13. Karakuş $S$, Rollas $S$. Synthesis and antituberculosis activity of new N-phenyl-N'-[4-(5-alkyl/arylamino-1,3,4thiadiazole-2-yl)phenyl]thioureas. Farmaco 2002; 57: 577-81.

14. Oruç EE, Rollas $S$, Kandemirli F, Shvets $N$, Dimongo AS. 1,3,4-Thiadiazole derivatives. Synthesis, structure elucidation and strucuture-antituberculosis activity relationship investigation. J Med Chem 2004; 47: 6760-67.

15. Solak N, Rollas $S$. Synthesis and antituberculosis activity of 2-(aryl/alkylamino)-5-(4-aminophenyl)-1,3,4-thiadiazoles and their schiff bases. ARKIVOC 2006; 12: 173-181.

16. Zamani $K$, Faghihi $K$, Mehraniani MS. Synthesis of some new 2,5-disubstituted 1,3,4-thiadiazoles containing isomeric pyridyl as potent antimicrobial agents. Pol J Pharmacol 2003; 55: 1111-17.

17. Güzeldemirci NU, Küçükbasmacı Ö. Synthesis and antimicrobial activity evaluation of new 1,2,4-triazoles and 1,3,4-thiadiazoles bering imidazo[2,1-b]thiazole moiety. Eur J Med Chem 2010; 45: 63-8.

18. Amir M, Shikha K. Synthesis and anti-inflammatory, analgesic, ulcerogenic and lipid peroxidation activities of some new 2-[(2,6-d,chloroanilino)phenyl]acetic acid derivatives. Eur J Med Chem 2004; 39: 535-45.

19. Rollas S, Kokyan Ş, Koçyiğit-Kaymakçığlu B, ÖzbaşTuran S, Akbuğa J. Synthesis and evaluation of cytotoxic activities of some substituted isoxazolone derivatives. Marmara Pharm J 2011; 15: 94-9.

20. Matysiak J. Evaluation of antiproliferative effect in vitro of some 2-amino-5-(2,4-dihydroxyphenyl)-1,3,4-thiadiazole derivatives. Chem Pharm Bull 2006; 54: 988-91.

21. Kuş C, Ayhan-Kılcıgil G, Özbey S, Kaynak FB, Kaya M, Çoban T, Can-Eke B. Synthesis and antioxidant properties of novel N-methyl-1,3,4-thiadiazol-2-amine and 4-methyl2H-1,2,4-triazole-3(4H)-thione derivatives of benzimidazole class. Bioorg Med Chem 2008; 16: 4294-303.

22. Khan I, Ali $S$, Hameed $S$, Rama NH, Hussain MT, Wadood A, Uddin R, Ul-Hag Z, Khan A, Ali S, Choudhary I. Synthesis, antioxidant activities and urease inhibition of some new 1,2,4-triazole and 1,3,4-thiadiazole derivatives. Eur J Med Chem 2010; 45: 5200-207.

23. Siddiqui $N$, Ahsan $W$. Triazole incorporated thiazoles as a new class of anticonvulsants: Design, synthesis and in vivo screening. Eur J Med Chem. 2010; 45: 1536-43.

24. Küçükgüzel ŞG, Küçükgüzel İ, Tatar E, Rollas $S$, Şahin $F$, Güllüce M, De Clercq E, Kabasakal L. Synthesis of some novel heterocyclic compounds derived from diflunisal hydrazide as potential anti-infective and anti-inflammatory agents. Eur J Med Chem 2007; 42: 893-901.

25. Dündar $Y$, Çakır B, Küpeli E, Şahin MF, Noyanalpan N. Synthesis of some new 1-acylthiosemicarbazides and 1,2,4-triazol-5-thiones, and their analgesic and anti-inflammatory activities. Turk J Chem 2007; 31: 301-13.

26. El-Emam AA, Ibrahim TM. Synthesis and anti-inflammatory and analgesic activity of some 3-(1-adamantyl)4-substituted-5-mercapto-1,2,4-triazoles. Arzneim-Forsh/Drug Res 1991; 41: 1260-64.

27. Labanauskas L, Udrenaite E, Gaidelis $P$, Brukstus A. Synthesis of 5-(2,3- and 4-methoxyphenyl)-4H-1,2,4triazole-3-thiol derivatives exhibiting anti-inflammatory activity. Farmaco 2004; 59: 255-9.
28. Kumar H, Javed SA, Khan SA, Amir M. 1,3,4-Oxadiazole/thiadiazole and 1,2,4-triazole derivatives of biphenyl-4-yloxy acetic acid: Synthesis and preliminary evaluation of biological properties. Eur J Med Chem 2008; 43: 2688-98.

29. Colanceska-Ragenovic K, Dimova V, Kakurinov V, Molnar DG, Buzarovcka A. Synthesis, antibacterial and antifungal activity of 4-substituted-5-aryl-1,2,4-triazoles. Molecules 2001; 6: 815-24.

30. Karakuş $S$, Çoruh U, Barlas-Durgun B, Vázquez-López EM., Özbaş-Turan S, Akbuğa J, Rollas S. Synthesis and cytotoxic activity of some 1,2,4-triazoline-3-thione and 2,5-disubstituted-1,3,4-thiadiazole derivatives. Marmara Pharm J 2010; 14: 84-90.

31. Mavrova TA, Wesselinova D, Tsenov YA, Denkova P. Synthesis, cytotoxicity and effects of some 1,2,4-triazole and 1,3,4-thiadiazole derivatives on immunocompetent cells. Eur J Med Chem 2009; 44: 63-9.

32. Turan-Zitoni $G$, Kaplancıklı ZA, Yildız MT, Chevalent $P$, Kaya D. Synthesis and antimicrobial activity of 4-phenyl/cyclohexyl-5-(1-phenoxyethyl)-3-[N-(2-thiazolyl) acetamido]thio-4H-1,2,4-triazole derivatives. Eur J Med Chem 2005; 40:607-13.

33. Doğan HN, Duran A, Rollas S. Synthesis and preliminary anticancer activity of new $1 \mathrm{H}-4,5$-dihydro-3-(3-hydroxy2-naphthyl)-4-substituted-1,2,4-triazole-3-thiones. Indian J Chem Sec B 2005; 44: 2301-7.

34. Hou YP, Sun J, Pang ZH, Lv PC, Li DD, Zhang HJ, Zheng EX, Zhao J, Zhu HL. Synthesis and antitumor activity of 1,2,4-triazoles having 1,4-benzodioxan fragment as novel class of potent methionine aminopeptidase type II. Bioorg Med Chem 2011; 19: 5948-54.

35. Akhtar T, Hameed S, Al-Masoudi NA, Khan KM. Synthesis and anti-HIV activity of new chiral 1,2,4-triazoles and 1,3,4-thiadiazoles. Heteroatom Chem 2007; 18: 316-22.

36. Abu Safieh KA, Al-Titi AMS, Zahra JA, Ayoub MT. Oxidative cyclization of arylidene carboxyhydrazides: Synthesis of substituted hydroxydiphenylmethyl-1,3,4oxadiazoles. Jordan J Chem 2007; 2: 211-8.

37. Mossman T. Rapid colorimetric assay for cellular growth and survival: Application to proliferation and cytotoxicity assays. J Immunol Methods 1983; 65: 55-63.

38. Beekman AC, Barentsen AR, Woerdenbag HJ, Uden WV, Pras N. Stereochemistry-dependent cytotoxicity of some artemisinin derivatives. J Nat Prod 1997; 60: 325-30.

39. Ilhan E, Ergenç N, Uzun M, Kaya D. Synthese von 6-Benzyliden-2-(a, a-diphenyl-a-hydroxyacetyl)thiazolo[3,2-b]-s-triazol-5-onen als potentiell biologisch wirksame Stoffe. Arch Pharm 1994; 327: 825-6.

40. Rollas S. Synthesis and spectroscopic data of some 1,3,4-thiadiazoles. J Fac Pharm İstanbul 1982; 18: 3-12.

41. Rollas S. Synthesis and spectrometric analysis of some 1,2,4-triazoline-5-thiones. J Fac Pharm İstanbul 1981; 17: 155-63.

42. Rollas S. Bazı l-aroil-4-alkil/ariltiyosemikarbazidler I. Doğa Bilim Dergisi 1983; Tıp Cilt 7: 65-73.

43. Ergenç N, Ilhan E, Ötük G. Synthese und biologische Wirkung einiger 1,4-disubstituierter Thiosemicarbazide und deren 1,2,4-Triazol-5-thion-Derivate. Pharmazie 1992; 47: 59-60.

44. Kalyoncuoğlu N, Rollas $S$, Sür-Altıner D, Yeğenoğlu $Y$, Anğ Ö. 1-[p-(Benzoylamino)benzoyl]-4-substitutedthiosemicarbazides. Synthesis and antibacterial and antifungal activities. Pharmazie 1992; 47:796-7. 